in the history of the philosophy of science. Among the ton essay reviews may be montioned I. T. Whiteside's discussion of the soientifie papers of Nowton; R. W. Southern on technology and history; and D. S. T. Cardwoll on scionce in the ninotoonth eontury. History of Science is editod by $\Lambda$. C. Crombie and M. A. Hoskin and published by W. Heffer and Sons, Ltd., Cambridge (papor bound, 21s. not; (eloth bound, 30s. net).

\section{The Society for the Promotion of Nature Reserves}

THE 1963 Handbook of the Society for the Promotion of Nature lieserves includos, bosides the forty-ninth annual roport covoring the year ondod March 31, 1963, and the accounts and balance sheet, a report on the Council for Nature, membership of which has risen to 339 , and lists of tho socioty's reserves and local coms. mittoes, officers and Council, Naturalists' Trusts and members and associates ( 1 p. 44. London: Tho Society for the Promotion of Nature Roserves, British Musoum (Natural History), 1963. 10s.). Annoxes to the report list purchascs complotod during the yoar with tho aid of the Nuffield Loan Fund. 'Tho roport includes briof accounts of activities during the year on the Soeinty's own reservos, and in that relating to Duncer's End, Buckinghamshire, roference is made to the pillage of wild flowers and tho diffioulty of rostricting such pillago.

\section{African Engravings and Decorations}

Twe Museu do Dundo, run by the Portugueso Dimmond Co. of Angols (Diamang), has long boon famous for its splendid publications concerned with the cultures, past and prosent, of tho country. The latest, Cabaças Gravadas da Lunda, by Mário Fontinha and Acácio Videira, is concerned with the ongravings and decorations on calabashes, which are used to-day as drinking-vessels, mugs, funnols, boxes, otc. (Publicacoes Culturais No. 57. Pp. 178 (34 plates). Lisboa: Companhia de Diamantos do Angola, 1963). Tho engravings are mado with a sharp knifo, the blade boing thick or thin according to tho losser or greater dolieacy of the strokes to bo made. Tho volume is largely a picturo book illustrating a considerable number of theso engravings. For tho most part, convontionalized human boings are depictod, somo of them very amusing to look at. But animals, equally stylizod, and patterns also occur. One intoresting figure represents a man driving a motorcar. The economy of lino would probably pleaso miny modern Furopean artists. For those interested in prohistoric and primitivo art it is always woll to tako note of a modorn art group mado by modorn primitivo peoplos. This work can be strongly recommondod, both for its sciontific value and as an intriguing picture book.

\section{Distance of the Andromeda Galaxy}

The late Dr. W. Baade was intorested in extending our knowledge of tho stollar populations and obtaining a moro accurate distance of the Andromeda Galaxy. For this purpose ho solocted a numbor of fiolds at varying distanees from the centre of the Galaxy and obtained it large numbor of photographs. The results for one field have now been comploted by his associato, Miss $\mathrm{H}$. H. Swopo (Astronomical J.6 68, 435; 1963). Thoy refer to a field $96^{\prime}$ south procoding tho nuclous in a very distant outor spira] arm, solectod for its low contont of absorbing matorial. More than 150 variablo stars have boon found, and. of these, twonty Cepheids have boon investigated in dotail, obtaining brightnosses and poriods of variation. The Andromoda cepheids are systematically reddened in comparison with those in our own ( Yolaxy, but it is thought that this reddoning arises mainly in our Galaxy and not in tho Andromoda Canlaxy. The Cepheids aro further from the eentre of the Andromoda (Kalaxy than the Sun is from the centre of our own Galnxy. The unreddenod distance modulus turns out to be $+24 \cdot 20$ magnitudes. The distanee is 690 kiloparsees $(2 \cdot 25$ million light yoars) with an uncortainty of at least 50 kiloparsoces.

\section{Textile Research at the Lódz Technical University}

THe theory of flow in the multi-branched siphon is developed in No. 9 of the Textile Sciences (Wlokiennictwo) sories of the Scientific Bulletin of the Lódz T'echnical University (Zeszyly Naukoue Politechniki Lodzkiej). 'This siphon is the main feature of Prof. Attanazy Boryniec's invention for spinning staplo viscose fibros in a hydraulically closod system to which gasos harmful to hoolth may be confined. Other papers deal with the role of sulphuric arid in the acetylation of collulose; the uso of molarnineurea-formaldehyde mixed precondensates for imparting crease recovery to linens and viscoso flax blends; benzyla. tion of cellulose; stability of knots in fishing nets; structural changes in polyacrylonitrile fibres during drawing and heat troatment. All papers are in Polish, but there are Russian and English summarios, which are sometimes extonsive. The Bulletin is mimeographed and appours about onco a yeur. It is edited by Dr. Witold Zurok, and copies are obtainable from Rodakcja Wydawnictw Naukowych Politochniki łobdzkiej, Lódź, Gdiriska 155, Poland.

\section{New Coagulant Aids for Removal of Suspended Particles}

Flocovlants fucilitrting removal of suspended solids from sewago and industrial wastos, also in pre-treatment of raw water similarly charged, aro now roinforced with what aro described as ". . . now eoagulant aids . . . liquid, water-misciblo polyamines (cationis polyelectrolytes)". These products aro known as 'Primofloc $C-3$ ' and 'Primofloc $C-5$ ' and are now being offored on a commercial scalo by Rohm and Hass, Philadelphia, Pa., well known for their manufactures of plastics, synthotic rosins and chomicals for many industrial applications. A rocent issue of the Rohm and Haas Reporter (21, No. 3; MayJune, 1963), a colourful and informativo houso-organ (distributod in Britain by Jonnig (homicals, Ltd., Bedford low, London, W.C.1), gives full dotails of these compounds, also of the many technical services offerod in the wide field of their international activities.

\section{Treatment of Tuberculosis}

Bhyorte the advont of potent and anti-tuberoulous drugs, the rooovory of pationts dopondesa entirely on natural and acquirod resistance augmonted by supporting trostmont. 'This inevitably resultod in a high mortality. With the uso of anti-tuberculous drugs, ospocially streptomycin, isonicotinio acid hydrazide and para-aminosalicylic acid, the prognosis of this formorly doadly disease changed for the better. The application of adronocorticotrophic hormone or adrenal cortionstoroids and their analogues achieved equally promising results. When hormonos wore first used, reports wore discouraging becanse the hormone was given alone or for the treatment of anothor disoase without enough knowledge of the underlying tuberculous lesion. 'To-day, combined treatment is increasingly used and ofton without knowlodgo of all the facts. $A$ communicstion by Drs. Somchai Bovornkitti, Prasort Kangsadal, Pairojana Oonsombatti and Damrong Bejrablaye of the Departmonts of Modicine and Physiology, Faculty of Modicine, and Sirjej IIospital, University of Medical Scioncos, Dhonburi, Thailand, roports their experionce on the use of prednisone concurrontly with conventional anti-tuberculous treatment in casos of tuberculous plourisy with effusion (Japanese Journal of Tuberculosis, 10, No. 1.2, June, 1962). Twonty-threo cases of plourisy with effusion, prosumably tuboronlons in origin, woro troatod with a combinod régime of prednisono and convontional anti-tuboroulous drugs. Prodnisone was used for a month. The results indionto that the combined treatrment is superior to the convontional anti-tuberculous remedies used alono. The results of troatmont were attributed to the desensitizirg properties of prodnisone on tuberculin hyporsensitivity. 